\title{
A Comparative Analysis of the Export Performances of China and India: Evidence from US Imports
}

\author{
Sadequl Islam
}

\begin{abstract}
This paper compares the export performances of China and India, the two largest labour-abundant countries. The empirical analysis of the paper is based on US imports from these two countries at the ten-digit level for 1992-2012. The paper examines the composition of exports from China and India, the degree of concentration of exports, and the extent of export similarity. The paper also explores the nature of product differentiation based on unit prices of exports from China and India. The empirical analyses show that China's shares in the US market, for both high-technology products and labour-intensive products, are substantially higher than that of India. Furthermore, China's export basket, compared to India's, is more diversified, and that the extent of export similarity between China and India in the US market is quite low. The data on unit prices of exports suggest that China has outperformed India in vertically differentiated products.
\end{abstract}

Index Terms-Concentration, export similarity, product differentiation, unit prices.

\section{INTRODUCTION}

China and India are prototypes of large labour-abundant countries which have been experiencing rapid economic growth based on outward-looking trade policy regimes. Based on the traditional Hecksher-Ohlin trade model, one could hypothesize that the two countries' export baskets overlap to a large extent. Recent trade data, however, suggest that volumes and baskets of exports from China and India differ substantially. In 2012, US exports to China amounted to $\$ 110.5$ billion while imports from China $\$ 425.6$ billion, with a deficit of $\$ 315.1$ billion. In contrast, US exports to India amounted to $\$ 22.1$ billion while imports from India amounted to $\$ 40.5$ billion, with a deficit of $\$ 18.4$ billion. Furthermore, in advanced technology products ${ }^{1}$ while the United States had a trade deficit of $\$ 119.1$ billion with China in 2012 , it had a trade surplus of $\$ 1.7$ billion with India. This suggests that China's basket of exports to the United States is more technologically sophisticated than India's.

Manuscript received March 13, 2014; revised June 9, 2014.

The author is with the Department of Economics, Laurentian University, Canada (e-mail: sislam@laurentian.ca).

${ }^{1}$ Advanced technology products meet the following criteria: a) the product is from a recognised high technology field; b) the product represents leading edge technology in the relevant field; and c) the product constitutes a significant part of items covered in the relevant field. According to the U.S. Census Bureau, advanced technology products consist of ten product groups: advanced materials, aerospace, biotechnology, electronics, flexible manufacturing, information and communications technology, life science, optoelectronics, nuclear technology, and weapons.
The main objective of this paper is two-fold: 1) to ascertain the similarities or differences between China's and India's exports; and 2) to relate the empirical findings to traditional and new trade theories of trade that emphasize firm heterogeneity and product differentiation.

This paper uses the US annual import data from 1992-2012 at the HS 10-digit level, available from the US Census Bureau. The paper presents some trade statistics on China's and India's exports to the United States and examines the Export Similarity Index (ESI) of China and India and the Hirschman-Herfindahl Index (HHI) of concentration in the US market for the 1992-2012 period. The paper also examines the number and ranking of products at the 10-digit level exported by China and India to the United States since 1992. Finally, the paper focuses on product and quality differentiation concerning China's and India's exports to the United States. It examines the unit-value ratios of China's exports to India's exports to the United States at the 10-digit level. Ratios greater than one may suggest that China exports higher-quality products compared to India - supporting the quality ladder model of Grossman and Helpman [1]. Ratios less than one however may support efficiency-sorting models and suggest that China's firms being more productive than their Indian counterparts have lower marginal costs and charge lower prices.

The paper is organized as follows. The second section presents a review of the relevant theoretical and empirical literatures. The third section presents some basic statics on US imports from China and India. The fourth section reports the main empirical findings based on the disaggregated data at the HS10-digit level. A final section makes some concluding remarks.

\section{A ReVIEW OF THE LITERATURE}

Since China and India are large labour-abundant countries, the traditional Hecksher-Ohlin trade theory predicts that these two countries typically export labour-intensive products. Accordingly, this theory further predicts that there will be a high degree of overlap or similarity between exports of China and India. China and India share another unique feature: they combine a large relative supply of low-skilled labour with an ample absolute supply of high-skilled labour. The absolute number of skilled workers is likely to influence the range of manufacturing products which a country exports. Furthermore, China and India may be able to diversify their exports at an earlier stage of development than did other Eat Asian countries such as South Korea, Japan, and Taiwan, as discussed in UNCTAD [2].

Recent trade theories, however, emphasize that countries 
export differentiated products from the same industry, for examples, the quality-ladder model of Grossman and Helpman and the Krugman model [3] which is based on Dixit-Stiglitz preferences [4]. The Krugman model, incorporating the "love-of-variety" focuses on horizontally differentiated products.

The trade theory based on firm heterogeneity emphasizes the fact that both exporting and non-exporting firms coexist in the same industry and that characteristics differ substantially across firms with significant implications for quality, productivity, and efficiency. More productive firms have superior export performance because they export high quality products at higher prices. This version of the model predicts a direct relationship between productivity and export prices and may be labeled as quality sorting model. However, more productive firms become more successful exporters because they have lower marginal costs and charge lower prices. This version of the model predicts a negative correlation between productivity and export prices and may be labeled as "efficiency sorting model."Bernard, Redding, and Schott [5] extends the efficiency-sorting model by concentrating on differences in the extent of horizontal product differentiation across sectors and countries. Their model predicts that labour-abundant countries would export more varieties of labour-intensive products while capital-abundant countries would export more varieties of capital-intensive products.

There is now a large literature on the rapid expansion of China's exports. Several studies by Rodrick [6] and Schott [7] have observed the increasing sophistication of China's exports. Several studies, for example, Greenaway, Mahabir, and Milner [8] have explored whether China's exports displace exports from other developing countries. The study by Kiyota [9] has found that China's exports highly overlap with US exports in the Japanese market. Kiyotaargues that China's export performance cannot be explained by the standard Ricardian or Hecksher-Ohlin model.

The literature on the comparative trade performances of China and India is scanty. Bhuyan [10] and Kalirajan and Singh [11] have examined the trade performances of China and India. Pohit and Basu [12] have explored India's export performance in high-technology products. These studies observe that India's export performance, especially in high-technology products, is far behind that of China.

This paper contributes to the literature in several ways. First, it explores the export performances of China and Indiathe two large emerging countries apparently with similar factor endowments based on data for the 1992-2012 period. Second, the paper uses highly disaggregated data at the ten-digit (HS Code) level. Third, the paper examines the export performances of China and India based on imports into the United States. Finally, the paper investigates, based on data on unit prices, whether China's export basket relative to India's export basket, reflects the dominance of quality sorting model or efficiency sorting model.

\section{BASIC STATISTICS}

This section presents some basic statistics on exports from China and India to the United States. Table I reports the values of total imports from China and India during the 1992-2013 period. It also shows the shares of China and India in the US market. It is clearly evident that US imports from China have steadily increased from $\$ 25.7$ billion in 1992 to over $\$ 425.6$ billion in 2012 . The market share of China has increased from only $4.8 \%$ in 1992 to $18.7 \%$ in 2012. The US imports from India increased from $\$ 3.8$ billion in 1992 to about $\$ 35.9$ billion in 2012. The market share of India increased from only $0.7 \%$ in 1992 to $1.78 \%$ in 2012 . During the January-October period, the market shares of both China and India increased from those in 2012. Table I highlights the fact that China exports more than ten times that of India to the United States.

TABLE I: US IMPORTS FROM CHINA AND INDIA: 1992-2013

$\begin{array}{lllll}\text { Year } & \text { China } & \text { India } & \text { SChina(\%) } & \text { SIndia(\%) } \\ 1992 & 25727.6 & 3779.821 & 4.83 & 0.71 \\ 1993 & 31539.9 & 4553.672 & 5.43 & 0.78 \\ 1994 & 38786.7 & 5309.499 & 5.85 & 0.80 \\ 1995 & 45543.2 & 5726.245 & 6.13 & 0.77 \\ 1996 & 51512.6 & 6169.506 & 6.48 & 0.78 \\ 1997 & 62557.6 & 7322.435 & 7.19 & 0.84 \\ 1998 & 71168.7 & 8237.182 & 7.80 & 0.90 \\ 1999 & 81788.2 & 9070.834 & 7.98 & 0.89 \\ 2000 & 100018.4 & 10686.63 & 8.21 & 0.88 \\ 2001 & 102278.3 & 9737.173 & 8.96 & 0.85 \\ 2002 & 125192.5 & 11818.33 & 10.78 & 1.02 \\ 2003 & 152436.1 & 13055.29 & 12.13 & 1.04 \\ 2004 & 196682.0 & 15572.04 & 13.38 & 1.06 \\ 2005 & 243470.1 & 18804.17 & 14.55 & 1.12 \\ 2006 & 287774.4 & 21830.82 & 15.52 & 1.18 \\ 2007 & 321442.9 & 24073.26 & 16.43 & 1.23 \\ 2008 & 337772.6 & 25704.38 & 16.06 & 1.22 \\ 2009 & 296373.9 & 21165.97 & 19.00 & 1.36 \\ 2010 & 364943.9 & 29532.59 & 19.08 & 1.54 \\ 2011 & 399335.6 & 36167.4 & 18.09 & 1.64 \\ 2012 & 425,578.9 & 40,514.1 & 18.7 & 1.78 \\ 2013 & 362,766.9 & 35,954.6 & 19.1 & 1.90\end{array}$

Table II, Panel A, reports top ten China's exports to the United States in 1992 and 2012 at the two-digit level. In 1992, the top ten items are toys, electrical machinery, footwear, apparel, leather products, knitted apparel, nuclear reactors, plastics, furniture, and mineral fuel. In three labour-intensive product categories china's share in the US market is quite high: toys (36.5\%), leather products $(34.6 \%)$, and footwear (33.5\%). Panel B of Table II shows the figures for top ten exports from China to the United States in 2012. Several points are noteworthy. First, China's market share in the US has dramatically increased for the top ten categories. For instance, China's market share in toys has increased from $36.5 \%$ in 1992 to $81.3 \%$ in 2012 . Second, a comparison of information in Panel A and Panel B reveals that China's exports to the US have become more sophisticated. In 2012, the top two product categories were electrical machinery and nuclear products. Two categories (leather products and mineral fuel) which appear on the list in 1992 do not belong to the list in 2012. Two new product categories which appear on the list in 2012 are articles of iron or steel and vehicles. 
However, China's market share in vehicles (HS Code 87) is still quite low.

Table III presents data on top ten US imports from China in 1992 and 2012, at the 10-digit level. Panel A demonstrates that in 1992, the top ten product categories are dominated by labour-intensive products such as toys, footwear, and apparel. In contrast, as reported in Panel B, in 2012, the top ten product categories are dominated by high-technology or information-technology products. Furthermore, in 2012, in eight out of ten product categories, China's market shares in the US were more than $60 \%$.

Figures under China and India are in millions of US dollar. Schina represents the share of imports from China to the United States as a percentage of total imports from the world to the United States. Sindia denotes the share of imports from India as a percentage of total imports from the world to the United States.

Figures for 2013 are for the January-October 2013 period.

TABLE II: CHINA's TOP 10 PRoducts (Two-DigIT) 1992 AND 2012 PANEL A: 1992

\begin{tabular}{|l|l|l|}
\hline Commodity & Value(US\$)in Thousands & Share of US Imports(\%) \\
\hline 95 Toys, Games \& Sport Equipment; Parts \& Accessories & 3683825.3 & 36.5 \\
\hline 85 Electric Machinery Etc; Sound Equip; Tv Equip; Pts & 3432484.3 & 5.0 \\
\hline 64 Footwear, Gaiters Etc. And Parts Thereof & 3402300.9 & 33.5 \\
\hline 62 Apparel Articles And Accessories, Not Knit Etc. & 3070283.2 & 17.1 \\
\hline 42 Leather Art; Saddlery Etc; Handbags Etc; Gut Art & 1558295.0 & 34.6 \\
\hline 61 Apparel Articles And Accessories, Knit Or Crochet & 1400630.9 & 13.6 \\
\hline 84 Nuclear Reactors, Boilers, Machinery Etc.; Parts & 1056131.3 & 1.4 \\
\hline 39 Plastics And Articles Thereof & 785399.4 & 9.8 \\
\hline 94 Furniture; Bedding Etc; Lamps NesoiEtc; Prefab Bd & 685795.8 & 9.6 \\
\hline 27 Mineral Fuel, Oil Etc.; BituminSubst; Mineral Wax & 511957.1 & 0.9 \\
\hline
\end{tabular}

\begin{tabular}{|l|l|l|}
\hline Commodity & Value, thousands, US\$ & Share of US Imports(\%) \\
\hline 85 Electric Machinery Etc; Sound Equip; Tv Equip; Pts & $110,670,655,403$ & 38.0 \\
\hline 84 Nuclear Reactors, Boilers, Machinery Etc.; Parts & $99,132,552,162$ & 32.2 \\
\hline 94 Furniture; Bedding Etc; Lamps Nesoi Etc; Prefab Bd & $22,442,930,610$ & 50.6 \\
\hline 95 Toys, Games \& Sport Equipment; Parts \& Accessories & $21,978,326,295$ & 81.3 \\
\hline 64 Footwear, Gaiters Etc. And Parts Thereof & $17,148,078,529$ & 71.8 \\
\hline 61 Apparel Articles And Accessories, Knit Or Crochet & $14,984,966,081$ & 36.4 \\
\hline 62 Apparel Articles And Accessories, Not Knit Etc. & $14,711,248,863$ & 40.0 \\
\hline 39 Plastics And Articles Thereof & $12,149,455,684$ & 28.9 \\
\hline 87 Vehicles, Except Railway Or Tramway, And Parts Etc & $9,388,164,336$ & 3.9 \\
\hline 73 Articles Of Iron Or Steel & $9,368,207,462$ & 24.9 \\
\hline
\end{tabular}

Source of Data: US Department of Commerce

TABLE III: CHINA’s TOP 10 PRODUCTS (10- DIGIT) 1992 AND 2012 PANEL A: 1992

Commodity

9503906000 Other Toys Not Having A Spring Mechanism (x)

6402991560 Oth Ftwr/upper $>90 \%$ R/p Exc Tennis/sandl Type Women (prs)

9503411000 Stuffed Toys (no)

2709002000 Crude Petroleum Testing 25 Degrees Api Or More (bbl)

6206100040 W/g Blouses Of Silk Cont 70\% More Silk, Not Knit (doz)

6403999060 Ftwr So R/p Up Lth Exc Pgs Ot VI Ov \$2.50/pr Women (prs)

6702903500 Artifical Flowers, Of Man-made Fibers (x)

6110900040 W/g Sweater Ot Tex Mat Assembled Hong Kong, Knit (doz)

6110900042 W/g Sweaters Of Other Textile Materials, Knit (doz)

9503490020 Non-metal Toys Not Having A Spring Mechanism (no)
Value (US\$) in Thousands Share of US Imports(\%)

\begin{tabular}{|r|r|}
\hline 644346.7 & 67.7 \\
\hline 579737.0 & 76.9 \\
\hline 482968.1 & 66.9 \\
\hline 467807.1 & 1.5 \\
\hline 442317.8 & 76.6 \\
\hline 341237.0 & 21.0 \\
\hline 339366.8 & 80.7 \\
\hline 325782.4 & 99.4 \\
\hline 307692.2 & 56.4 \\
\hline 285233.3 & 75.7 \\
\hline
\end{tabular}

PANEL B: 2012

\begin{tabular}{|l|l|l|}
\hline commodity & Value (US\$,thousands) & Share of US Imports (\%) \\
\hline 8471300100 Port Dgtl Adp Mach,\&lt; 10 Kg,at Least Cpu,kbrd,dsply (no) & $40,834,248.6$ & 94.6 \\
\hline
\end{tabular}




\begin{tabular}{|l|l|l|}
\hline 8517120050 Cellular Radiotelephones For Pcrs (no) & $32,516,730.9$ & 76.4 \\
\hline 8517620050 Mach For Recp/conver/etc Of Voice/image/data,nesoi (x) & $10,097,774.3$ & 38.5 \\
\hline 9503000073 Toys Pts \& Acces 15 Usc 2052 Persons 3 To 12 Nesoi (x) & $6,321,642.9$ & 87.0 \\
\hline 9504500000 Video Games Used With Tv Receiver, Parts \& Access (x) & $4,733,677.1$ & 95.8 \\
\hline 8443310000 Mach Prfm Gt=2 Funct Print/cpy/fax; Use W/ Atp/ntw (no) & $3,779,155.2$ & 79.5 \\
\hline 8473301180 Pts Adp Mch, Nt Incptng Crt,prt Crt Assem.;nesoi (x) & $3,747,479.0$ & 65.8 \\
\hline 8528510000 Monitors, Used W/ Adp Systems Of Head. 8471, Nesoi (no) & $3,139,265.7$ & 88.9 \\
\hline 8473305100 Pts \& Accessories Of Mach Of Heading Of 8471,nesoi (x) & $2,935,421.3$ & 69.4 \\
\hline 8471500150 Proc Unt In Hous W/ Either Stor, In\&output,w/o Crt (no) & $2,843,624.6$ & 18.8 \\
\hline
\end{tabular}

Table IV shows India's top export items, at the two-digit level, to the United States in 1992 and 2012. As displayed in Panel A, in 1992, the top ten items are dominated by primary products (for example, natural pearls and precious stones) and labour-intensive products such as apparel articles and carpets. Panel B reports the top ten export items in 2012. A comparison of Panel A and Panel B reveals several points. First, several categories which appear on the list in 1992 no longer appear in 2012: carpets, leather products, cotton and cotton materials, edible food products, and footwear. Second, several new product categories appear on the list for 2012: pharmaceutical products, organic chemicals, nuclear reactors, electrical machinery, and articles of iron or steelsuggesting increased sophistication of India's export basket to the United States. Finally, natural pearls and precious stone (HS Code 71) appears as the leading export item in 1992 as well as 2012 .

A comparison of top ten items from China and India to the United States at the two-digit level reveals three striking facts. First, compared to India, China's export basket to the United States has become more technologically sophisticated during 1992-2012. For instance, in 2012, the market share of
China in the United States in electrical machinery (HS Code 85 ) and nuclear reactors (HS Code 84 ) were $38.0 \%$ and $32.2 \%$. In contrast, the relevant figures of India were $0.5 \%$ and $0.7 \%$, respectively. Second, China's market shares in the United States in labour-intensive categories are also substantially higher compared to India. For instance, in 2012, the market share of China in the United States in apparel articles (HS code 62) was $40.0 \%$ compared to only $5.0 \%$ for India. Finally, it appears that India has managed to attain a comparative advantage in pharmaceutical products with a market share of $6.6 \%$ in the United States. In 2012, the pharmaceutical products - group was the second largest export item from India to the United States.

Table $\mathrm{V}$ presents figures on top export items, at the ten-digit level, from India to the United States in 2012. It is evident from Panel A and Panel B that India's export items are dominated by primary products and labour-intensive products. In 1992 as well as 2012, non-industrial diamonds were the leading export item. In contrast, in 2012, China's export basket, at the ten-digit level, was dominated by high-technology items, as already observed from Table III, panel B.

TABLE IV: INDIA's TOP 10 PRODUCTS (Two-DigIT) TO THE US, 1992 AND 2012 PANEL A: 1992

Commodity

71 Nat Etc Pearls, PrecEtc Stones, Pr Met Etc; Coin

62 Apparel Articles And Accessories, Not Knit Etc.

57 Carpets And Other Textile Floor Coverings

27 Mineral Fuel, Oil Etc.; BituminSubst; Mineral Wax

42 Leather Art; Saddlery Etc; Handbags Etc; Gut Art

52 Cotton, Including Yarn And Woven Fabric Thereof

08 Edible Fruit \& Nuts; Citrus Fruit Or Melon Peel

61 Apparel Articles And Accessories, Knit Or Crochet

63 Textile Art Nesoi; Needlecraft Sets; Worn Text Art

64 Footwear, Gaiters Etc. And Parts Thereof
Value ( US\$)in Thousands

1125837.7

744467.3

167599.4

139373.2

133214.5

128500.5

109023.6

83648.3

82952.1

81202.5
Share of US Imports (\%)

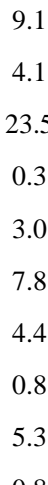

0.8

PANEL B: 2012

\begin{tabular}{|l|c|c|}
\hline Commodity & Value( US\$,thousands) & Share of US Imports(\%) \\
\hline 71 Nat Etc Pearls, Prec Etc Stones, Pr Met Etc; Coin & $7,161,223$ & 11.1 \\
\hline 30 Pharmaceutical Products & $4,223,475$ & 6.6 \\
\hline 13 Lac; Gums, Resins \& Other Vegetable Sap \& Extract & $3,522,326$ & 81.2 \\
\hline 27 Mineral Fuel, Oil Etc.; Bitumin Subst; Mineral Wax & $3,261,417$ & 0.8 \\
\hline
\end{tabular}




\begin{tabular}{|l|c|c|}
\hline 29 Organic Chemicals & $2,177,902$ & 4.1 \\
\hline 84 Nuclear Reactors, Boilers, Machinery Etc.; Parts & $2,157,149$ & 0.7 \\
\hline 63 Textile Art Nesoi; Needlecraft Sets; Worn Text Art & $1,939,927$ & 16.0 \\
\hline 62 Apparel Articles And Accessories, Not Knit Etc. & $1,834,260$ & 5.0 \\
\hline 85 Electric Machinery Etc; Sound Equip; Tv Equip; Pts & $1,471,481$ & 0.5 \\
\hline 73 Articles Of Iron Or Steel & $1,468,300$ & 3.9 \\
\hline
\end{tabular}

Source of Data: US Department of Commerce

TABLE V: INDIA's ToP TEN PRODUCTS ( 10 -DigiT) To THE US, 1992 AND 2012 PANEL A: 1992

\begin{tabular}{|l|r|r|}
\hline Commodity & Value (US\$) Thousands & Share of US Imports(\%) \\
\hline 7102390010 Nonindustrial Diamonds Weighing \&lt;/= 0.5CT Each (car) & $935,161.2$ & 58.3 \\
\hline 6206303040 Wmns Bls, shrt,cot, w Lt 2 Clrs In Wrp A/o Fill (doz) & $136,415.1$ & 21.6 \\
\hline 2710002500 Naphthas, Exc Mtr Fuel Or Mtr Fuel Blndg Stock (bbl) & $135,824.2$ & 11.9 \\
\hline 0801300000 Cashew Nuts, Frsh Or Dried, Whether/not Shelled (kg) & $108,650.7$ & 42.0 \\
\hline 7113195000 Gold Or Platinum Jewelry, Plt/cld Or Not, Nesoi (x) & $106,350.3$ & 6.0 \\
\hline 6206303010 Women's Blouses Cot With Gt=2 Color Warp, Nt Kn (doz) & $72,154.6$ & 36.4 \\
\hline 5701102090 Textile Carpeting, Knotted, Wool/fah Nesoi (sqm) & $56,104.1$ & 32.5 \\
\hline 6206403030 Women's Blouses Of mmf Lt 36\% Flax Fib Nt Knit (doz) & $55,011.0$ & 8.5 \\
\hline 0306130040 Shrimps And Prawns, Frozen, Peeled (kg) & $50,202.2$ & 8.2 \\
\hline 6205202065 Men's Cotton Shirts Nesoi, Not Knit (doz) & $49,786.4$ & 7.5 \\
\hline
\end{tabular}

PANEL B: 2012

\begin{tabular}{|l|l|l|}
\hline Commodity & Value (thousands,US\$) & Share of US Imports(\%) \\
\hline 7102390050 Nonindustrial Diamonds Weighing \&gt; 0.5CT Each (car) & 3895648.9 & 22.3 \\
\hline 1302320020 Mucilage \& Thickener W/n Modified, From Guar Seed (kg) & 3371337.3 & 97.4 \\
\hline 2710124590 LghtOil, prep Of OthrHydcbnMix,ntBiodiesl,nesoi (bbl) & 1986671.5 & 26.7 \\
\hline 7102390010 Nonindustrial Diamonds Weighing \&lt;/= 0.5CT Each (car) & 1502475.7 & 68.6 \\
\hline 3004909120 Cardiovascular Medicaments, Nesoi (kg) & 1043508.5 & 16.4 \\
\hline 7113195085 Jewelry And Parts Thereof, Of Gold, Nesoi (x) & 1040422.6 & 27.6 \\
\hline 6302319020 Sheets, Cotton, Not Printed/knitted/napped/trim (no) & 575890.9 & 54.5 \\
\hline 6302600020 Towels Except Dish Of Terry Toweling Fabric (no) & 526548.7 & 36.6 \\
\hline 2710191150 Heavy Fuel Oils,distl/resd,gt=25 Deg,not Biodiesel (bbl) & 445819.8 & 13.7 \\
\hline 3004909135 Antidepressants, Tranquilizers,other Psych Agt,nes (kg) & 434147.6 & 22.7 \\
\hline
\end{tabular}

Source of Data: US Department of Commerce

\section{EXPORT CONCENTRATION AND EXPORT SIMILARITY: CHINA AND INDIA}

Trade liberalization through the World Trade Organization has expanded the volume of trade involving the United States, China, and India. It is instructive to examine whether and to what extent the export baskets of China and India have become more diversified or less concentrated across product categories. Furthermore, it is important to explore the extent of similarity of the export baskets of China and India.

The degree of export concentration can be measured by Hirschman-Herfindahl Index which is defined as follows:

$$
\mathrm{HHI}=\left[\left(\sum S_{i}^{2}\right)^{1 / 2}-(1 / n)^{1 / 2}\right] /\left[1-(1 / n)^{1 / 2}\right]
$$

where $S_{i}=$ the share of ith product in total exports from China ( or India) to the United States, $n=$ the number of products.

The HHI can range from 0 to 1 , the latter implying the highest degree of concentration where by all exports are accounted for by only one export product. The closer the value of HHI to zero, the greater is the diversity of exports. The HHI values for China and India are calculated at the ten-digit level (HS Code).

Table VI reports the HHI values for China and India for the 1992-2012period. It is evident that the values of HHI of China are lower than those of India. In 2012, the HHI of China was 0.141 , compared to a value of 0.143 of India. The figures clearly indicate that China's exports are more diversified (less concentrated) compared to India. Table VI also shows that for India, the HHI shows a downward trend during 1992-2009 and a stable pattern during 2010-2013. For China, the HHI doesn't show a clear trend. It appears that since 2003, China's HHI shows an upward trend and that the HHI values of China and India have converged.

To explore, the extent of export similarity, this paper uses the Export Similarity Index (ESI) which is defined as follows, as in Finger and Kreinin [13].

$$
\mathrm{ESI}=\sum \operatorname{Min}\left\{S_{i C}, S_{i I}\right\}
$$


where $S_{i C}$ is the share of the ith export item in China and $S_{i I}$ is the share of the ith export item in India. The ESI can range from zero to unity, the latter implying a complete similarity of the export baskets of the two countries in the US market. The ESI values are computed at the ten-digit level. The ESI figures are reported in Table VI. The ESI values appear to be low and these values haven't substantially changed: It was 0.147 in 1992 and 0.183 in 2012. The figures suggest that at the ten-digit level, the export baskets of China and India are quite dissimilar.

TABLE VI: PRODUCT CONCENTRATION AND EXPORT SiMILARITY INDEX:

\begin{tabular}{|c|c|c|c|}
\hline \multicolumn{4}{|c|}{ CHINA AND INDIA } \\
\hline Year & ESI & HHI China & HHI India \\
\hline 1992 & 0.147 & 0.057 & 0.248 \\
\hline 1993 & 0.153 & 0.056 & 0.257 \\
\hline 1994 & 0.086 & 0.032 & 0.042 \\
\hline 1995 & 0.155 & 0.048 & 0.208 \\
\hline 1996 & 0.158 & 0.050 & 0.203 \\
\hline 1997 & 0.162 & 0.050 & 0.185 \\
\hline 1998 & 0.157 & 0.058 & 0.194 \\
\hline 1999 & 0.151 & 0.055 & 0.216 \\
\hline 2000 & 0.157 & 0.052 & 0.199 \\
\hline 2001 & 0.171 & 0.048 & 0.166 \\
\hline 2002 & 0.161 & 0.052 & 0.181 \\
\hline 2003 & 0.168 & 0.057 & 0.165 \\
\hline 2004 & 0.164 & 0.065 & 0.157 \\
\hline 2005 & 0.183 & 0.069 & 0.143 \\
\hline 2006 & 0.19 & 0.070 & 0.145 \\
\hline 2007 & 0.189 & 0.078 & 0.134 \\
\hline 2008 & 0.195 & 0.080 & 0.115 \\
\hline 2009 & 0.195 & 0.099 & 0.114 \\
\hline 2010 & 0.188 & 0.106 & 0.147 \\
\hline 2011 & 0.157 & 0.115 & 0.146 \\
\hline 2012 & 0.183 & 0.141 & 0.143 \\
\hline
\end{tabular}

Note: Computed from the data of US Department of Commerce

\section{EXPORT VARIETIES AND PRODUCT DIFFERENTIATION}

Trade liberalization increases not only the volume of trade between countries but also the varieties of goods that are traded. This section examines the expansion of export varieties from China and India to the United States. It also explores the nature of product differentiation of exports from China and India to the United States based on the data on unit price ratios.

Table VII presents the number of products, at the ten-digit level, exported by China and India to the United States during 1992-2012. It is evident that the number of products exported from China rose steadily from 6,602 in 1992 to 13,614 in 2012.For India, the number of products increased from 3,446 in 1992 to 8,770 in 2012. China clearly exports more varieties to the United States, compared to India. It is noteworthy that during 2009, a period of great Recession, the number of export varieties from China and India dropped. This section of the paper now explores the nature of product differentiation involving exports from China and India to the United States. The empirical analysis is based on the data on unit price ratios (UPR). The UPR is defined as the ratio of unit price of China's exports and the unit price of India's exports. Following the methodology of Kiyota (2010), the following categories of product differentiation are considered:

1) Vertically Differentiated Products reflecting quality differences (VDQ). For these products UPR> 1.25

2) Horizontally Differentiated Products reflecting variety differences (HDP). For these products, the following condition holds: $0.8 \leq \mathrm{UPR} \leq 1.25$

3) Vertically Differentiated products reflecting efficiency difference (VDE). For these products, UPR $<0.8$

Table VIII reports the number and proportions of three categories of products, VDQ, HDP, and VDE for the 1992-2012period. It is evident that the proportion of vertically differentiated products reflecting quality differences (VDQ) shows a falling trend declining from 0.339 in 1992 to 0.166 in 2012. The proportion of horizontally differentiated products reflecting variety differences (HDP) appears to be stable at 0.21; however, in 2012 the proportion declined to 0.143 . In contrast, the proportion of vertically differentiated products reflecting efficiency differences (VDE) appears to show an upward trend, rising from 0.443 in 1992 to 0.691 in 2012. This suggests that China by producing on a global scale, has managed to achieve lower average costs and unit prices for its exports compared to India ${ }^{2}$.

TABLE VII: EXPORT VARIETIES FROM CHINA AND INDIA TO THE U.S.A

\begin{tabular}{|l|l|l|}
\hline Year & China & India \\
\hline 1992 & 6602 & 3446 \\
\hline 1993 & 7002 & 3872 \\
\hline 1994 & 7591 & 4296 \\
\hline 1995 & 7918 & 4603 \\
\hline 1996 & 8283 & 4873 \\
\hline 1997 & 9043 & 5425 \\
\hline 1998 & 9254 & 5610 \\
\hline 1999 & 9671 & 5740 \\
\hline 2000 & 10206 & 6163 \\
\hline 2001 & 10310 & 6346 \\
\hline 2002 & 11068 & 6734 \\
\hline 2003 & 11472 & 6997 \\
\hline 2004 & 11995 & 7306 \\
\hline 2005 & 12702 & 7827 \\
\hline 2006 & 13114 & 8177 \\
\hline 2007 & 13161 & 8286 \\
\hline 2008 & 13090 & 8302 \\
\hline 2009 & 13053 & 8017 \\
\hline 2010 & 13236 & 8301 \\
\hline 2011 & 13467 & 8577 \\
\hline 2012 & 13614 & 8770 \\
\hline So & Dee & \\
\hline
\end{tabular}

Source of Data: US Department of Commerce

${ }^{2}$ This is consistent with the evidence that China's market share in the United States involving labour-intensive products such as apparel is much higher compared to India. 
TABLE VIII: PRODUCT DIFFERENTIATION OF EXPORTS FROM CHINA AND

\begin{tabular}{|c|c|c|c|c|c|c|}
\hline & & & INDI & & & \\
\hline Year & VDQ & $\begin{array}{l}\text { VDQ } \\
\text { (Prop) }\end{array}$ & HDP & $\begin{array}{l}\text { HDP } \\
\text { (Prop) }\end{array}$ & VDE & $\begin{array}{l}\text { VDE } \\
\text { (Prop) }\end{array}$ \\
\hline 1992 & 698 & 0.339 & 450 & 0.218 & 913 & 0.443 \\
\hline 1993 & 821 & 0.339 & 512 & 0.212 & 1086 & 0.449 \\
\hline 1994 & 798 & 0.300 & 600 & 0.226 & 1262 & 0.474 \\
\hline 1995 & 965 & 0.325 & 637 & 0.214 & 1368 & 0.461 \\
\hline 1996 & 1114 & 0.346 & 680 & 0.211 & 1424 & 0.443 \\
\hline 1997 & 1258 & 0.343 & 756 & 0.206 & 1652 & 0.451 \\
\hline 1998 & 1289 & 0.336 & 818 & 0.213 & 1735 & 0.452 \\
\hline 1999 & 1397 & 0.341 & 809 & 0.198 & 1890 & 0.461 \\
\hline 2000 & 1396 & 0.309 & 975 & 0.216 & 2143 & 0.475 \\
\hline 2001 & 1380 & 0.298 & 969 & 0.209 & 2280 & 0.493 \\
\hline 2002 & 1500 & 0.299 & 1036 & 0.207 & 2478 & 0.494 \\
\hline 2003 & 1537 & 0.288 & 1057 & 0.198 & 2738 & 0.514 \\
\hline 2004 & 1609 & 0.284 & 1144 & 0.202 & 2915 & 0.514 \\
\hline 2005 & 1442 & 0.232 & 1307 & 0.210 & 3468 & 0.558 \\
\hline 2006 & 1586 & 0.242 & 1409 & 0.215 & 3554 & 0.543 \\
\hline 2007 & 1621 & 0.243 & 1343 & 0.201 & 3717 & 0.556 \\
\hline 2008 & 1587 & 0.239 & 1395 & 0.210 & 3669 & 0.552 \\
\hline 2009 & 1516 & 0.234 & 1290 & 0.200 & 3660 & 0.566 \\
\hline 2010 & 1582 & 0.233 & 1390 & 0.205 & 3811 & 0.562 \\
\hline 2011 & 1652 & 0.237 & 1450 & 0.208 & 3875 & 0.550 \\
\hline 0 & 1717 & 0.166 & 1480 & 0.1 & 16 & 0.69 \\
\hline
\end{tabular}

\section{CONCLUding Remarks}

India and China are two large labour-abundant emerging countries. Accordingly, the two countries' export baskets are expected to overlap substantially. The empirical findings of this paper however, reveal several differences between China and India. First, the data, both at two-digit and ten-digit levels, show that China's export basket to the United States has shifted toward high-technology products, compared to India. Second, China's market shares in the US market, for both high-technology products and labour-intensive products, are substantially higher than India's market shares. Third, compared to India, China's export basket has been more diversified in the US market. Fourth, the extent of export similarity between China and India in the US market appears to be quite low. This, of course, doesn't imply that there is little or no competition between China and India. Finally, the data on unit prices of exports from China and India reveal that China has outperformed India in vertically differentiated products reflecting efficiency differences.

The findings of this paper seem to support the new trade theories which emphasize product differentiation rather than the standard Hecksher-Ohlin model.

\section{REFERENCES}

[1] G. Grossman and E. Helpman, Innovation and Growth in the Global Economy, Cambridge: MIT Press, 1991.

[2] UNCTAD, Trade and Development Report, Geneva: United Nations, 2005.

[3] P. Krugman, "Increasing returns, monopolistic competition, and international trade," Journal of International Economics, vol. 9, no. 4, pp. 469-479, 1979.

[4] A. Dixit and J. Stiglitz, "Monopolistic competition and optimum product diversity," American Economic Review, vol. 67, pp. 297-308, 1977.

[5] A. B. Bernard, S. J. Redding, and P. K. Schott, "Comparative advantage and heterogeneous firms," Review of Economic Studies, vol. 74, pp. 31-66, 2007.

[6] D. Rodrick, "What is so special about china's exports?" China and World Economy, vol. 14, no. 5, pp. 1-19, 2006.

[7] P. K. Schott, "The relative sophistication of Chinese exports," Economic Policy, vol. 23, pp. 5-49, 2003.

[8] D. Greenaway, D. A. Mahabir, and C. Milner, "Has China displaced other Asian countries' exports?" China Economic Review, vol. 19, pp. 152-169, 2008.

[9] K. Kiyota, "Are US exports different from China's exports? Evidence from Japan's imports," The World Economy, pp. 1302-1324, 2010.

[10] P. Bhuyan, "International trade in goods: performance of India vis-à-vis a few important economies in South and East Asia," Reserve Bank of India Occasional Papers, vol. 25, pp. 105-133, 2004.

[11] K. Kalirajan and K. Singh, "A comparative analysis of China's and India's recent export performances," Asian Economic Papers, vol. 7, no. 1, pp. 1-28, 2008.

[12] S. Pohit and S. Basu, "High-technology merchandise exports: Where does India stand?" South Asia Economic Journal, vol. 13, no. 2, pp. 183-206, 2012.

[13] J. Finger and M. E. Kreinin, “A measure of 'export similarity' and its possible use,” Economic Journal, vol. 89, pp. 905-12, 1979.

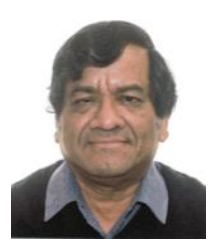

Sadequl Islam is a professor of economics at Laurentian University, Ontario, Canada. He obtained an M.A. and a Ph.D. degrees in economics from the University of Manitoba. He is the author of a book named "The textile and clothing industry of Bangladesh in a changing world economy," published by the University Press and the Centre for Policy Dialogue. He has published in many scholarly journals and presented papers at many international conferences. His research fields include international trade, applied econometrics, macroeconomics, and Asian economies. 